\title{
Multilingualism as a Tool of Marginalization or Empowerment in Pakistan: A Classroom Perspective
}

\author{
Musarrat Azher ${ }^{1}$, Riffat-un-Nisa Awan ${ }^{2}$, Ghazala Noureen ${ }^{3}$
}

\begin{abstract}
Pakistani educational system is dominated by multilingual phenomenon at all stages. The students with different levels of language proficiency enter university education where classrooms are dominated by multilingual phenomenon with the main adherence to English language. The major concerns of this study are: does multilingualism in Pakistani university classrooms transfer or inculcate any sense of marginalization or empowerment amongst the students at BS level; whether this sense of marginalization or empowerment can be related to their socioeconomic background and to their private and public schooling. The data were collected through a self-developed questionnaire from BS $3^{\text {rd }}$ semester students enrolled in University of Sargodha. The questionnaire included close ended as well as open ended items which were analyzed both qualitatively and quantitatively. The results revealed that students with low socio-economic background and public schooling were on the verge of marginalization and demotion which have developed a sense of low confidence in them. Students from private sector English medium schools were more confident, interactive, and participative in the classroom, hence empowered. The study concluded with some suggestion that universities may organize a zero semester for students to teach them a deficiency course of communication skills in English.
\end{abstract}

Keywords: Multilingualism, Marginalization. Empowerment, University students

\section{Introduction}

Pakistan is a multilingual country where seventy five different languages are used for interactive purposes (Rahman, 1995). Like many other Asian countries Pakistan has adopted a tripartite language policy, having Urdu as dominant national language along with a local/regional language and accompanied by English language generally taught at primary and secondary school levels. The purpose of this confused policy is to accommodate diverse requirements, i.e. providing education to everyone with diverse mother tongues, developing national identity through competence in national language, and being

\footnotetext{
${ }^{1}$ Lecturer, Department of English, University of Sargodha

${ }^{2}$ Associate Professor, Department of Education, University of Sargodha, Email: riffarukh@gmail.com

${ }^{3}$ Assistant Professor, Institute of Education, Lahore College for Women University
} 
a part of global world through English (Canagarajah \& Ashraf, 2013; Jayasundara, 2014; Rahman, 1995, 2008). Globalization effects developing communities in their use of local languages in education by negatively effecting the promotion of local values and directly contributing to a marginalization of these languages and their speakers (Stroud, 2003).

Since the establishment of Pakistan, little or no systematic attention has been paid to the language policy both in terms of planning and implementation of medium of instruction at primary, secondary and tertiary levels. In 1959, for example, the Commission on National Education recommended to upgrade the status of Urdu from lingua franca to national language "on a par with national anthem." In 1973, Urdu was again declared as the national language of Pakistan and that arrangements would be made for Urdu being used for official purposes within 15 years from the day of commencement. Meanwhile English may be used as official language until arrangements would be made for its replacement with Urdu (Javed, 2017). Gen. Zia ul Haq, in 1980s, started 'Islamization' of laws with a new language policy. Arabic was introduced as a compulsory subject in schools and colleges.

The Language Policy given in the National Education Policy (Govt. of Pakistan, 2009) acknowledges the importance of English language as a language of international competition, whereas Urdu as a link language which connects people. It talks about the 'Vision 2030' which describes the reality on the ground "the divide between the prevalent school structure and differences in levels of infrastructure and facilities, media of instruction, emolument of teachers, and even examination systems between public and private sectors (Coleman \& Capstick, 2012). The rich send their children to privately run English medium schools which offer foreign curricula and examination systems; the public schools enroll those who are too poor to do so". Considering the situation, National Education Policy (Govt. of Pakistan, 2009) offered about the status planning of English and Urdu recommending the use of Urdu as the medium of instruction in public schools with an emphasis on English language teaching. The state's current educational policy (Govt. of Pakistan 2017) talks little about the language policy in Pakistani schools at primary and secondary level, though favors Urdu as the national language and English as an official language. As for medium of instruction, Urdu or local languages are recommended as medium of instruction at primary level, "Medium of Instructions for all subjects at primary level shall be either local language or national language (Urdu)" whereas English will be included as a compulsory subject from grade 1 (Govt. of Pakistan, 2017, p. 49). No recommendations are given about language to be used at secondary level. 
In such a confused and abstruse state, where government is disinterested to devise any sound language policy, the matter of language policy has essentially become a prerogative of the owners of the private school systems and principals and teachers of public schools. The ambivalence has resulted in four different types of education systems in Pakistan on the grounds of English as a medium of instruction: English in private elite institutions and only rich are entitled to send their kids; Urdu and English in private middle and lower middle class schools; Urdu in government schools; and Arabic and Urdu or local languages in madrassas. These systems are widespread in urban areas. Even another system is prevalent in rural areas where GTM is still in practice and English and other subjects are taught through local languages. Each of these systems follows a different pattern of curricula, examination, materials and culture resulting into division amongst different strata of Pakistan and has created and highlighted a breach between students in terms of fluency in English.

Students from such a variety of education systems when enter public universities make a transition from multilingual education to English medium education and form many sub-populations/ sub -groups on the bases of fluency in English language within the realm of broader student population/group with different social-economic and academic background. English language is considered a basis of economic and social segregation in Pakistani society. In this scenario, our discussion is about whether the multilingual phenomenon in educational system has led students to the feelings of marginalization or empowerment in the context of university education where medium of instruction is mainly English and where the teachers emphasize the use of "only English". The study, therefore, seeks answers to the following research questions:

1. Do Pakistani undergraduate students feel marginalized or empowered during class room interaction?

2. Do the students' feelings of being marginalized or empowered relate to their private/ public schooling and socio-economic background?

\section{Literature Review}

According to Oxford Advanced Learner's Dictionary, to 'marginalize' is "to make somebody or a group of people become or feel less important and less powerful"; whereas, to empower is defined as "to give somebody the authority or power to act" (Hornby, Cowie, \& Lewis, 1974). In the context of university education, as is the focus of current research the two concepts are connected with the power, students are rendered in the process of classroom interaction. The two concepts are associated with the classroom participation, the ways students interact with their teachers, peers and learning materials. In such participation, those who interact with freedom and ease are empowered, and those whose 
freedom and comfort level are constrained are marginalized. According to Vygotsky's perspective (Phillips \& Soltis, 1998, p. 55), "language is considered as a controlling device for easing this freedom and ability to interact; and, in this sense, it is a potential means for both empowering and marginalizing learners". It is important therefore, that in order to avoid the marginalization of some learners, a language that is the medium of instruction in schools is carefully chosen and well taught so that all learners are free and able to interact through it.

Marginalization of students may be due to multiple reasons like socioeconomic background, knowledge gap or cultural and communication barriers. The issue has been addressed in multiple researches while suggesting pedagogical ways to reduce/ minimize the intensity of the issue and maintain the humanity of the students. Many researches have been conducted addressing the need to empower those who feel themselves on the verge of marginalization during schooling. Freire (2018) stressed the need to focus attention to those secondary school students who are marginalized and suggested pedagogical ways to allow marginalized students to maintain their humanity. Kozol (2005) in his book, the Shame of the Nation, exposes the shameful levels of segregation present in American school systems. Kozol visited 60 different American schools and noted the system of inequality that prevails in US on the basis of finance and white and non-white color. He narrated that many of the nation's public schools have become "“apartheid schools' in which 99 to 100 percent of students are nonwhite".

Many other studies relate the issue of marginalization or empowerment with the medium of instruction. Mtana and O-saki (2015) address this issue in relation to Tanzanian secondary school children who are taught through Tanzanian local language (Kiswhili) at primary level and English in secondary and higher education. They argue that because of the existing policy that allows only English in secondary schools, many students who enter these schools become marginalized because they are not fluent enough to use English for communication and for learning school subjects. They consider the socio economic factor as a strong reason for this issue by stating that only rich parents are entitled to send their children in private schools and that form a small group of the overall population of the school but enough to let poor students feel marginalized. They suggest that learners' familiar language can be used to support the interaction in classrooms.

Some other studies have exclusively focused on proactive teaching strategies for marginalized students that can be helpful for creating better learning environment and lay the responsibility on teachers in mitigating the sense of being marginalized and creating progressive classroom environment. 
When teachers plan to manage the classroom, students become more engaged in a positive classroom environment (Guardino \& Fullerton, 2010). McMurray and Sorrells (2007) suggested that bureaucratization has negative impact on students' success, whereas, proactive collaboration guide to the recognition and implementation of additional processes, and attaining exemplary results for students' success. Akin and Neumann (2013) discuss the importance of collaboration for developing such strategies that help teachers to enhance readiness for the marginalized students.

\subsection{Research Design}

\section{Research Methodology}

The opinions of the students about empowerment and marginalization were explored using a survey method through descriptive research design. A five point likert scale of 28 items was used for data collection.

\subsection{Population and Sample}

The population of study was all students of BS programs studying in $3^{\text {rd }}$ semester at university of Sargodha, Pakistan. Two faculties, i.e. faculty of social science and faculty of arts and humanities were selected purposively. Three departments of these two faculties were reselected on the basis of simple random sampling technique. The sample of the study was 150 students (both male and female) enrolled in the $3^{\text {rd }}$ semester in the departments of Education, English and Graphic Designing of university of Sargodha, who were selected as participants through convenient sampling technique.

\subsection{Instrumentation}

Depending on the earlier studies, a survey questionnaire for the university students was established by the researchers. The questionnaire was developed to explore university students' feelings of being marginalized or empowered during classroom interaction. The questionnaire addressed the issue mainly from three perspectives in terms of students: Feeling Marginalized or Empowered when interacting in the Class; Feeling Marginalized or Empowered When the Teacher Delivers in the Class; Feeling Marginalized or Empowered when Interacting with Peers. To set the validity of the instrument, it was disseminated amongst some of the university English language teachers. The questionnaire was revised according to their feedback and instructions. Then the survey was piloted among 25 university students enrolled in the $3^{\text {rd }}$ semester in university of Sargodha. The results revealed some of the language expression as ambiguous and an overlap of some of the statements. Accordingly, the changes were made to eliminate the problems. The number of items in the questionnaire was reduced from 33 to 29 . In the end, final feedback was sought from two experts who did not suggest any further changes in the questionnaire. The scores 
against each statement were counted and proportion was calculated to determine the validity of the instrument. The questionnaire consisted of 28 close ended and 1 open ended statements.

\subsection{Data Collection}

Finally, the questionnaire was administered to 150 students (both male and female) enrolled in the $3^{\text {rd }}$ semester in the departments of Education, English and Graphic Designing of university of Sargodha. Each questionnaire was given a number as an ID of the student for qualitative data analysis.

\section{Data Analysis and Interpretations}

The data were further analyzed using SPSS to find out mean score along with ANOVA to explore statistically significant differences across departmental groups and schooling

\section{Feeling Marginalized or Empowered when Interacting in the Class}

\section{Table 4.1}

Percentage and mean scores of students who feel marginalized while interacting in the class

\begin{tabular}{|c|c|c|c|c|c|c|c|}
\hline $\mathrm{S} \#$ & Items & $\mathrm{SA}$ & $\mathrm{A}$ & $\mathrm{N}$ & $\mathrm{D}$ & SD & Mean \\
\hline 1 & I generally remain silent in the class & 12.3 & 33.0 & 22.6 & 23.6 & 8.5 & 2.72 \\
\hline 2 & $\begin{array}{l}\text { I consider myself not well versed in } \\
\text { English. }\end{array}$ & 6.6 & 27.4 & 25.5 & 35.8 & 4.7 & 2.95 \\
\hline 3 & $\begin{array}{l}\text { I remain silent in the class as I think I } \\
\text { am not good in English }\end{array}$ & 7.5 & 22.6 & 18.9 & 36.8 & 14.2 & 2.72 \\
\hline 4 & $\begin{array}{l}\text { I comfortably participate in the class } \\
\text { both in English and Urdu. }\end{array}$ & 17.9 & 40.6 & 23.6 & 13.2 & 4.7 & 3.53 \\
\hline 5 & I feel shy when I try to speak English & 15.1 & 34.9 & 17.0 & 26.4 & 6.6 & 3.41 \\
\hline 6 & $\begin{array}{l}\text { I think my other class fellows are } \\
\text { better than me in English }\end{array}$ & 12.3 & 25.5 & 25.5 & 27.4 & 9.4 & 3.03 \\
\hline 7 & $\begin{array}{l}\text { I feel the students who speak in } \\
\text { English are superior to me }\end{array}$ & 8.5 & 21.7 & 17.9 & 30.2 & 21.7 & 2.65 \\
\hline 8 & $\begin{array}{l}\text { I think the class is divided into } \\
\text { groups as per their participation in } \\
\text { the class }\end{array}$ & 15.1 & 34.2 & 17.0 & 25.5 & 7.5 & 3.61 \\
\hline 9 & $\begin{array}{l}\text { I feel I am better than other students } \\
\text { being proficient in English }\end{array}$ & 1.9 & 15.1 & 38.7 & 34.9 & 9.4 & 3.36 \\
\hline \multirow[t]{2}{*}{10} & $\begin{array}{l}\text { I think I can better express my ideas } \\
\text { in Urdu. }\end{array}$ & 42.1 & 28.3 & 18.9 & 6.6 & 3.8 & 4.15 \\
\hline & $\begin{array}{l}\text { Feeling Marginalized or Empowered } \\
\text { when Interacting in the Class }\end{array}$ & & & & & & 3.14 \\
\hline
\end{tabular}

The table 4.1 demonstrates the results about students' feelings of marginalization or empowerment while interacting in the class. It is shown that majority of the students prefer silence during classroom interaction $(\mathrm{M}=2.72)$, considering themselves deficient in English $(\mathrm{M}=2.95)$. These students believe 
that they could better contribute in class room interaction if allowed to speak in Urdu $(\mathrm{M}=4.15)$ and that the students are divided into two groups on the basis of their proficiency in English $(\mathrm{M}=3.61)$. A strong feeling of marginalization is seen to be prevalent amongst majority of the students, as they consider their class fellows better than they are in English ( $\mathrm{M}=2.65)$.

\section{Feeling Marginalized or Empowered When the Teacher Delivers in the Class}

Table 4.2

Percentage and mean scores of students feeling marginalized when teacher delivers in the class

\begin{tabular}{|c|c|c|c|c|c|c|c|}
\hline S\# & Items & SA & A & $\mathrm{N}$ & $\mathrm{D}$ & SD & Mean \\
\hline 1 & $\begin{array}{l}\text { I do not understand anything the teacher } \\
\text { says in the class in English }\end{array}$ & 7.5 & 5.7 & 15.1 & 35.8 & 35.8 & 2.13 \\
\hline 2 & $\begin{array}{l}\text { I do not understand course material and } \\
\text { texts books }\end{array}$ & 2.8 & 9.4 & 15.1 & 48.1 & 24.5 & 2.34 \\
\hline 3 & $\begin{array}{l}\text { I feel when the teacher switches from } \\
\text { one language to another, it makes me } \\
\text { confused and perplexed. }\end{array}$ & 09 & 10.4 & 18.9 & 46.2 & 23.6 & 2.18 \\
\hline 4 & $\begin{array}{l}\text { I feel myself inferior to the class when I } \\
\text { am unable to understand when the } \\
\text { teacher speaks in English }\end{array}$ & 2.8 & 17.0 & 17.0 & 39.6 & 23.6 & 2.35 \\
\hline 5 & $\begin{array}{l}\text { I feel the teacher prefers to communicate } \\
\text { with those students who are good in } \\
\text { English }\end{array}$ & 16.0 & 20.8 & 24.5 & 23.6 & 15.1 & 2.99 \\
\hline 6 & $\begin{array}{l}\text { I feel teacher pays more attention to the } \\
\text { students who are good in English. }\end{array}$ & 9.4 & 22.6 & 23.6 & 28.3 & 16.0 & 2.81 \\
\hline 7 & $\begin{array}{l}\text { I feel teachers give more marks to the } \\
\text { students who are good in English. }\end{array}$ & 17.9 & 37.7 & 20.8 & 16.0 & 7.5 & 3.42 \\
\hline 8 & $\begin{array}{l}\text { I feel I can get better scores if teacher } \\
\text { communicates with me in the class. }\end{array}$ & 30.2 & 30.2 & 22.6 & 13.2 & 3.8 & 2.30 \\
\hline 9 & $\begin{array}{l}\text { I feel myself neglected and marginalized } \\
\text { when I do not understand what the } \\
\text { teacher is saying in the class. }\end{array}$ & 14.2 & 20.8 & 27.4 & 25.3 & 12.3 & 2.99 \\
\hline 10 & $\begin{array}{l}\text { I feel understanding teacher talk and } \\
\text { course material will empower me in the } \\
\text { class. }\end{array}$ & 23.6 & 33.0 & 28.3 & 15.1 & .0 & 3.65 \\
\hline \multirow[t]{2}{*}{11} & $\begin{array}{l}\text { The group that speaks well in the class is } \\
\text { teacher's favorite. }\end{array}$ & 24.5 & 29.2 & 21.7 & 13.2 & 11.3 & 3.43 \\
\hline & $\begin{array}{l}\text { Feeling Marginalized or Empowered } \\
\text { When the Teacher Delivers in the Class }\end{array}$ & & & & & & 2.77 \\
\hline
\end{tabular}

Table 4.2 exhibits the results about students' feelings of marginalization or empowerment while teacher delivers in the class. The results reveal that a small portion of students feel uncomfortable in understanding of teacher's lectures $(\mathrm{M}=2.13)$, course materials and texts books in English $(\mathrm{M}=2.34)$. However, majority of the students have indicated teachers' favoritism and a 
tendency of giving more marks $(\mathrm{M}=3.42)$ and attention $(\mathrm{M}=3.43)$ to those considered proficient in English. Moreover, the students hold a strong realization that understanding teachers' talk and course material in English will empower them in class $(\mathrm{M}=3.65)$.

\section{Feeling Marginalized or Empowered when Interacting with Peers}

Table 4.3

Percentage and mean scores of students feeling marginalized when interacting with peers

\begin{tabular}{|c|c|c|c|c|c|c|c|}
\hline $\begin{array}{l}\mathrm{S} \\
\#\end{array}$ & Items & SA & $\bar{A}$ & $\mathrm{~N}$ & $\bar{D}$ & SD & Mean \\
\hline 1 & $\begin{array}{l}\text { I feel marginalized in the group } \\
\text { discussion as I do not talk in English. }\end{array}$ & 5.7 & 24.5 & 26.4 & 34.0 & 9.4 & 2.83 \\
\hline 2 & $\begin{array}{l}\text { I get a weaker position in the group as I } \\
\text { do not talk in English. }\end{array}$ & 3.8 & 16.0 & 20.8 & 38.7 & 20.8 & 2.43 \\
\hline 3 & $\begin{array}{l}\text { I am impressed when the other students } \\
\text { speak in English in group discussion }\end{array}$ & 14.2 & 30.2 & 27.4 & 17.0 & 10.4 & 3.58 \\
\hline 4 & $\begin{array}{l}\text { The students who are good in English } \\
\text { look down upon those who are not }\end{array}$ & 10.4 & 19.8 & 33.0 & 22.6 & 14.2 & 2.89 \\
\hline 5 & $\begin{array}{l}\text { The students who are good in English } \\
\text { dominate group discussion }\end{array}$ & 16.0 & 32.1 & 25.5 & 24.5 & 1.9 & 3.35 \\
\hline 6 & I think I have better ideas than my peers & 9.4 & 24.5 & 36.8 & 19.8 & 9.4 & 2.95 \\
\hline 7 & $\begin{array}{l}\text { The students who do not speak in } \\
\text { English are kept aside. }\end{array}$ & 10.4 & 24.5 & 17.9 & 32.1 & 15.1 & 2.83 \\
\hline & $\begin{array}{l}\text { Feeling Marginalized or Empowered } \\
\text { when Interacting with Peers }\end{array}$ & & & & & & 2.93 \\
\hline
\end{tabular}

Table 4.3 shows results about students' feeling of marginalization or empowerment while interacting with peers during classroom discussion. The results indicate that students feel highly impressed and influenced by the students who speak in English $(\mathrm{M}=3.58)$ and that they feel such students dominating their less interactive peers. Almost $30 \%$ of the sample was feeling marginalized in the group discussion as they did not talk in English. A big majority believed that the students who were good in English dominated group discussions $(\mathrm{M}=3.35)$.

Table 4.4 
Volume VI- Issue II (December 2020)

Mean, SD and t test for feeling marginalized when interacting in the Class, with Peers and Teachers, of Public and Private school Students

\begin{tabular}{llllllcc}
\hline \multirow{2}{*}{ Class } & $\begin{array}{c}\text { School } \\
\text { Attended }\end{array}$ & Mean & SD & $t$ & Df & $\begin{array}{c}\text { Sig. }(2- \\
\text { tailed) }\end{array}$ & $\begin{array}{c}\text { Mean } \\
\text { Difference }\end{array}$ \\
& Public & 33.91 & 5.97 & 1.916 & 104 & .048 & 3.03 \\
Teachers & Private & 30.88 & 5.36 & & & & \\
& Public & 30.67 & 6.09 & .459 & 104 & .647 & .518 \\
& Private & 30.16 & 5.45 & & & & .452 \\
& Public & 20.73 & 4.11 & .544 & 104 & .588 & .452 \\
& Private & 20.28 & 4.44 & & & & \\
\hline
\end{tabular}

Table 4.4 demonstrates the results of mean difference of public and private schooling in relation to the feelings of marginalization or empowerment during classroom interaction. The results show that there were statically significant differences in the mean scores of students of private and public schools, feeling marginalized when interacting in the class $[t(104)=1.91, \mathrm{p}<.05]$. The mean score for public sector students is shown higher indicating more marginalized feelings on the part of those studied in public schools. Furthermore, the results indicate that there were no statically significant differences across private and public schooling, where the students' feel marginalized when interacting with teachers and peers, although the mean score for public sector students is shown higher indicating more marginalized feelings on the part of those studied in public schools.

Table 4.5

Mean, SD and t test for feeling marginalized when interacting in the class, with peers and teachers, for students of different socio-economic status

\begin{tabular}{lccccccc}
\hline \multirow{2}{*}{ Class } & Father's Income & Mean & SD & $t$ & $D f$ & $\begin{array}{c}\text { Sig. (2- } \\
\text { tailed) }\end{array}$ & $\begin{array}{c}\text { Mean } \\
\text { Difference }\end{array}$ \\
\multirow{4}{*}{ Teachers } & Less than 50000 & 33.78 & 5.63 & 1.991 & 104 & .046 & 3.09 \\
& More than 50000 & 30.69 & 5.87 & & & & \\
\multirow{2}{*}{ Peers } & Less than 50000 & 30.68 & 5.50 & .314 & 104 & .754 & .371 \\
& More than 50000 & 30.30 & 5.96 & & & & \\
& Less than 50000 & 20.94 & 4.08 & .754 & 104 & .452 & .656 \\
\hline
\end{tabular}

Table 4.5 exhibits the results of mean difference of the feelings of two groups of students in terms of their socio-economic status. The results show that there were statistically significant differences across two socio-economic groups. The students' having low socio economic status were feeling marginalized when interacting in the class $[t(104)=1.99, \mathrm{p}<.05]$. The results indicate that there were no statistically significant differences across two socio-economic groups where the students' feel marginalized when interacting with teachers and peers, although the mean was higher for the students with less than Rs. 50000 per 
month which means they were feeling more marginalized as compared to group with more than Rs. 50000 per month.

Table 4.6

ANOVA for feeling marginalized when interacting in the class, with peers, and teachers, of BS English, BS Education and BS Graphic Designing

\begin{tabular}{lllllll}
\hline & & $\begin{array}{l}\text { Sum of } \\
\text { squares }\end{array}$ & Df & $\begin{array}{l}\text { Mean } \\
\text { square }\end{array}$ & $F$ & Sig. \\
\hline Class & Between groups & 19.576 & 2 & 9.788 & .289 & .750 \\
& Within groups & 3490.320 & 103 & 33.887 & & \\
\multirow{5}{*}{ Teacher } & Total & 4733.858 & 105 & & & \\
& Between groups & 63.243 & 2 & 31.622 & .945 & .392 \\
& Within groups & 3446.795 & 103 & 33.464 & & \\
& Total & 3510.038 & 105 & & & \\
& Between groups & 25.772 & 2 & 12.886 & .706 & .496 \\
& Within groups & 1878.690 & 103 & 18.240 & & \\
& Total & 1904.462 & 105 & & & \\
\hline
\end{tabular}

The table 4.6 demonstrates ANOVA results comparing the feelings of students from different departments in relation to feeling marginalized or empowered while interacting in the class, while listening to the teachers and while interacting with peers. The results showed that there were no statistically significant differences among three departments which mean that all the groups i.e. students of BS English, BS Education and Graphic Designing were feeling equally marginalized or empowered.

\section{Students' Perception about Classroom Interaction}

The students were asked to respond to one open-ended statement to suggest on the ways teachers interact in classrooms. Majority of the students feel the presence of a strong segregation between the students on the basis of their proficiency and participation in English. They observe a sheer sense of marginalization on the part of those who are less favored and not encouraged in the course of class room interaction.

$$
\begin{aligned}
& \text { "The class is divided in two groups, those who } \\
& \text { participate and those who are not encouraged to } \\
& \text { participate." (ST. ID: 53) }
\end{aligned}
$$

It is not that the students are unaware of teacher's importance. Considering their teachers a ladder to support them rise up the skies, the students believe that the teachers can help shaping the future of the students through addressing and engaging those who are less empowered and neglected. 
"I suggest that teachers should make interaction better with those students who are weak and not so confident. Because when teachers communicate to those students they will obviously gain confidence and make better way to their bright future." (ST. ID: 124). "Teachers must encourage those students who can't speak English fluently. So that they do not feel neglected" (ST. ID: 29)

The students persistently seem to complain about the teachers' partiality and their predisposition towards those who are already good in speaking English. In a way they consider teachers as responsible for creating the niche for those who are empowered and consequently dominate the neglected and marginalized.

"Students must be given proper attention in the class. Teachers must encourage the students to speak in English. Mostly speaking group dominates the class and teachers favor them." (ST. ID: 57)

Majority of the students believe in their strengths and abilities which they can further be polished if they are addressed and not overlooked by the teachers.

\section{Discussion}

The findings of the study indicate that most of the students, while considering themselves deficient in English, prefer silence while interacting in the class. They strongly affirm that class is segregated between empowered and neglected marginalized students on the basis of their classroom participation in English. Norton (2001) proclaims that non-participation of students in the class may be due to a disconnection between students' interaction with peers and their teachers' curriculum goals. He further concludes that "marginality is a form of non-participation that prevents full participation" (p. 161). Such situations demand to identify the socially constructed nature of classroom interactions and participation and non-participation of students (Norton, 2001).

However, the students feel comfortable while teachers give their talk and while interacting with the course materials and text books. Though, they complain that teachers remain in pursuit of empowering those who are good in English by admiring, engaging and listening them. Mtana and O-saki (2015) have studied this issue in relation to Tanzanian secondary school children. They state that many students who enter these schools become marginalized because they are not fluent enough to use English for communication and for learning school 
subjects. This study tells the same story as respondents believe that the neglected ones could perform better if they had been listened to by the teachers.

The students have a strong feeling that the teachers do not bother about silent students and don't use their first language for explaining the difficult concepts. As (Cummins, 2005, p. 5) explains, "using both the more familiar and the second language provides learners with the opportunity to transfer cognitive and academic (or literacy) related proficiency from one language to another and can enhance the development of both languages". Teachers not noticing the inefficiencies of these students, avoiding paying attention to their problems and not listening to the sidelined students, in their pursuit of admiring those who are already good at English, consequently making "the rich, the richer and the poor, the poorer". In this way teachers are considered responsible for causing the intricacies of empowerment in a multilingual context and the new marginalisations that may result as a consequence and hence leading them towards low achievement. As Abedi and Gándara (2006) emphasize that learning in second language have much more impact on students' academic achievement than is acknowledged by educational practitioners, teachers and researchers. Such struggling students develop an identity of a less competent one, for not being actively involved in discussions, which further make their participation more difficult (Morita, 2004 ). Norton (2001) believes that teachers need to use strategies to assist or scaffold learners' comprehension of class discussions, which may help to facilitate their classroom participation. He further states that instead of considering students less able teachers and peers should treat such students as valuable cultural and intellectual resources.

As for the feelings during interaction amongst peers, the students feel impressed and mesmerized, consequently dominated by those who are good in English, thus causing the rest feel inferior and marginalized. It is not that students do not realize the importance of understanding teachers' talk and course material, and believe that teachers' attention and justice among the students can confiscate the intricacies. Norton (2001) suggests that teachers need to revisit their pedagogy and curriculum, and devise strategies in this regard to increase the participation of learners with different needs and to promote equal opportunity for participation in the classroom.

The findings on feeling marginalized or empowered while interacting with the class, in relation to schooling and the socio-economic status of the students indicate that those from public schools and with low socio-economic background are found more marginalized and neglected. The findings are similar to the situation in Tanzanian secondary schools as reported by Norman (2016) and Mtana and O-saki (2015) in that socio-economic factor proves to be a strong 
reason for feeling marginalized or empowered during classroom interaction. It is disheartening to know that such students who have fallen victim to the life situations are further affected in maintaining their university engagement and identities as students. Many of them lead a life of alienation, so marginalization becomes exacerbated. In essence, we are making our universities harvesting sites for more disengaged students, further marginalizing those who are already marginalized.

\section{Conclusions}

In the light of the findings, it is concluded that mostly students felt marginalized while interacting with the class and with peers. They felt inferior in the presence of students who were more vocal and were good at speaking English. They feel the prevalence of a strong segregation among the students on the basis of their proficiency in English and participation in the class discussions. They recognize a complete sense of marginalization for those who are less favored and not stimulated in class room interaction by the teachers and the peers.

The findings also indicate that those from public schools and with low socio-economic background are found more marginalized and ignored. It is disheartening to know that such students who have fallen victim to the life situations are further affected in maintaining their university engagement and identities as students. Many of them lead a life of alienation, so marginalization becomes exacerbated. In essence, we are making our universities harvesting sites for more disengaged students, further marginalizing those who are already marginalized. This situation raises the question that does linguistic marginalization results into social and academic marginalization? As students have claimed they could perform better by contributing better ideas in classroom discussions, had they been encouraged and paid more attention and care.

\section{Recommendations}

It is suggested that teachers must genuinely care for their students by attending and listening to those who need more attention and ears to be listened. There is a need of uniform language policy from primary to the graduation level. The government must take serious steps to plan and implement a uniform language policy throughout the country, the policy that eliminates segregation between rich and poor, strong and weak. The teachers need a lot of training on this issue. Deciding on and promoting language policies that oppose hierarchies of power, are crucial for social change as they promote social equity and foster change (Wedin \& Wessman, 2017).

As the most important responsibility lies with the teachers in giving voices to all the students, by engaging, listening and admiring those whose 
potentials remain secret. Learner centered pedagogical practices involving all the students may be introduced and implemented more cautiously. In such practice, learners are given the authority and power to act during learning. It is emphasized that the students' familiar language may be used advantageously to support the learning of subject content and to improve the learners' knowledge and skills of the second language.

\section{References}

Abedi, J., \& Gándara, P. (2006). Performance of English language learners as a subgroup in large-scale assessment: Interaction of research and policy. Educational Measurement: Issues and Practice, 25(4), 36-46.

Akin, I., \& Neumann, C. (2013). Identifying proactive collaboration strategies for teacher readiness for marginalized students. Journal of College Teaching \& Learning. 10(4), 235-244.

Canagarajah, S., \& Ashraf, H. (2013). Multilingualism and education in South Asia: Resolving policy/practice dilemmas. Annual Review of Applied Linguistics, 33, 258-285.

Coleman, H., \& Capstick, A. (2012). Language in education in Pakistan: Recommendations for policy and practice. Islamabad: British Council Islamabad.

Cummins, J. (2005). Teaching for cross-language transfer in dual language education: Possibilities and pitfalls. Paper presented at the TESOL Symposium on dual language education: Teaching and learning two languages in the EFL setting, Istanbul: Bogazici University.

Freire, P. (2018). Pedagogy of the oppressed. USA: Bloomsbury Publishing.

Govt. of Pakistan, (2009). National Education Policy. Ministry of Education, Islamabad.

Govt. of Pakistan, (2017). National Education Policy. Ministry of Federal Education and Professional Training, Islamabad.

Guardino, C. A., \& Fullerton, E. (2010). Changing behaviors by changing the classroom environment. Teaching Exceptional Children, 42(6), 8-13. 
Hornby, A. S., Cowie, A. P., \& Lewis, J. W. (1974). Oxford advanced learner's dictionary of current English (Vol. 4) London: Oxford University Press.

Javed, F. (2017). A Historical Perspective of Pakistan's Language in Education Policy. Language in India, 17(8), 45-55.

Jayasundara, N. S. (2014). The Development of Language Education Policy: An Indian Perspective; a View from Tamil Nadu. International Journal of Scientific and Research Publications, 4, 1-4.

Kozol, J. (2005). The shame of the nation: The restoration of apartheid schooling in America. NY: Broadway Books.

McMurray, A., \& Sorrells, D. (2007). Student services and the college classroom: Some ideas for collaboration. College Student Journal, 41(4), $1218-1223$.

Morita, N. (2004). Negotiating participation and identity in second language academic communities. TESOL Quarterly, 38(4), 573-603.

Mtana, N. J., \& O-saki, K. M. (2015). Empowering the marginalised through language supportive pedagogy in Tanzanian secondary education. Paper presented at the 11th Language \& Development Conference, New Delhi, India

Norman, P. C. (2016). Teacher attitudes and perceptions of low and high socioeconomic status students. (Unpublished Doctoral Dissertation) Utah State University, Logan, Utah.

Norton, B. (2001). Non-Participation, Imagined Communities, and the Language Classroom. In: M. Breen (Ed.), Learner Contributions to Language Learning: New Directions in Research (pp. 159-71). Harlow: Pearson Education.

Phillips, D., \& Soltis, J. F. (1998). Perspectives on learning. NY: Teachers College Press.

Rahman, T. (1995). Language planning and politics in Pakistan (Research Report Series Vol. No. 9). Islamabad: Sustainable Development Policy Institute. 
Rahman, T. (2008). Language policy and education in Pakistan. In S. M. N. Hornberger (Ed.), Language Policy and Political Issues in Education, Encyclopedia of Language and Education (2 ed., Vol. 1, pp. 383-392). New York: Springer.

Stroud, C. (2003). Postmodernist perspectives on local languages: African mother-tongue education in times of globalisation. International journal of bilingual education and bilingualism, 6(1), 17-36.

Wedin, Å., \& Wessman, A. (2017). Multilingualism as policy and practices in elementary school: Powerful tools for inclusion of newly arrived pupils. International Electronic Journal of Elementary Education, 9(4), 873890.

\section{Citation of this Article:}

Azher, M., Awan, R., \& Noureen, G. (2020). Multilingualism as a Tool of Marginalization or Empowerment in Pakistan: A Classroom Perspective. International Journal of Innovation in Teaching and Learning (IJITL), 6(2), 7994. 